\title{
Correction to: Organizational Ethical Virtues of Innovativeness
}

\author{
Elina Riivari ${ }^{1}$ - Anna-Maija Lämsä ${ }^{1}$
}

Published online: 8 February 2019

(c) The Author(s) 2019

\section{Correction to: J Bus Ethics https://doi.org/10.1007/s10551-017-3486-6}

The article Organizational Ethical Virtues of Innovativeness, written by Elina Riivari and Anna-Maija Lämsä, was originally published electronically on the publisher's internet portal (currently SpringerLink) on 3 March 2017 without open access.

With the author(s)' decision to opt for Open Choice the copyright of the article changed on 7 February 2019 to (c) The Author(s) 2019 and the article is forthwith distributed under the terms of the Creative Commons Attribution 4.0 International License (http://creativecommons .org/licenses/by/4.0/), which permits use, duplication, adaptation, distribution and reproduction in any medium or format, as long as you give appropriate credit to the original author(s) and the source, provide a link to the Creative Commons license and indicate if changes were made.

Publisher's Note Springer Nature remains neutral with regard to jurisdictional claims in published maps and institutional affiliations.

The original article can be found online at https://doi.org/10.1007/ s10551-017-3486-6.

Elina Riivari

elina.riivari@jyu.fi

Anna-Maija Lämsä

anna-maija.lamsa@jyu.fi

1 School of Business and Economics, University

of Jyvaskyla, Ohjelmakaari 10, P.O. Box 35,

40014 University of Jyvaskyla, Finland 